\title{
Communications
}

\section{Keratinoid corneal degeneration}

\author{
ALEG GARNER \\ Department of Pathology, Institute of Ophthalmology, University of London
}

From time to time the pathologist is confronted with histological sections of corneaeremoved for a variety of reasons - which show multiple globular deposits of an amorphous eosinophilic material embedded in the superficial layers. They usually occur as a secondary phenomenon, the first recorded description appearing to be that of Wedl ( $186 \mathrm{I}$ ) wherein the deposits followed trauma and secondary panophthalmitis (Fig. I). In ignorance of their precise nature and for want of a more explicit terminology, the deposits were originally referred to as either hyaline (Kamocki, 1892) or colloid (Baquis, 1898). Both terms are purely descriptive and even the definition of hyaline as applied by von Recklinghausen ( 1883 ) to define a substance which was homogeneous and highly refractile, resistant to all but the most concentrated acids and alkalis, and intensely acidophilic in its staining reactions does not sufficiently distinguish the deposits from the hyaline change commonly seen in old scar tissue. Parsons (1904) was well aware of the non-specificity of the term hyaline and reviewed the problem most thoroughly, but in the circumstances was not able to apply a more apposite nomenclature to describe what he referred to as "this special type of hyaline degeneration".

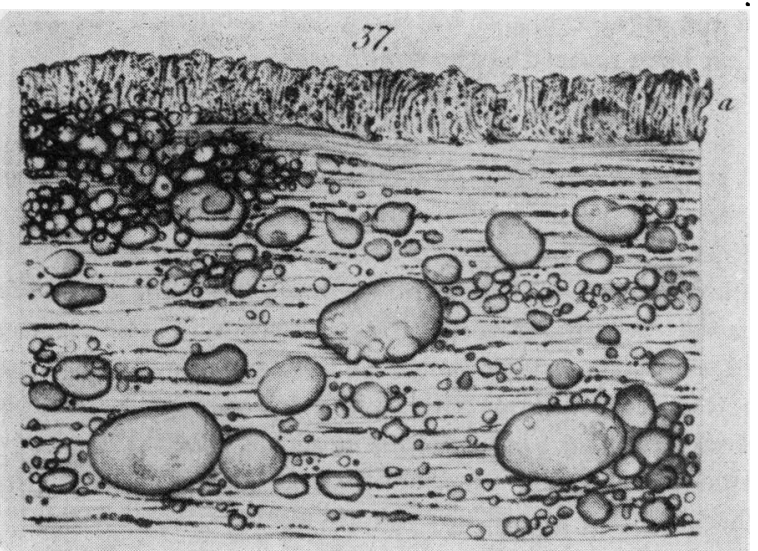

FIG. I Drawing of the deposition of globular material within the corneal stroma and epithelium after trauma and secondary panophthalmitis. From Wedl (186r), fig. 37

Morphologically identical material was subsequently described in corneal tissue from patients in whom there was no apparent predisposing pathology under such headings as "degeneratio corneae sphaerularis elaioides" (Lugli, I935; Bietti, 1962; Volpi and Serra 1967) and "degeneratio hyaloidea granuliformis corneae" (Kozlowski, 1953). Lugli (1935) regarded the condition as a probable consequence of senescence, but Bietti (1962)

This communication is dedicated to Prof. Dr. Josef Böck, Chief of the Second Eye Clinic of the University of Vienna, on the occasion of his 7oth birthday. 
doubted this since he had observed it also in young subjects, and it is probably true to say that in none of the circumstances in which the hyaline globules are formed is there any real understanding of their aetiology or pathogenesis. Similarly, there is but scant information as to the nature of the deposits, little having been learnt since Best (I900) showed that they were composed, at least in part, of a tyrosine-containing protein.

The object of the present study has been to seek further information concerning the composition and origin of this hyaline material by the application of histochemical staining methods.

\section{Material and methods}

Five corneal specimens were examined. Three were full-thickness discs from patients with lattice dystrophy in whom the condition was complicated by the presence of globular hyaline material in the superficial stroma. Two were partial-thickness discs, one from a man with unexplained bandshaped opacities, and the other from a patient with opacities attributed to long-standing trauma.

The specimens were fixed in formol saline and sections were prepared from paraffin-embedded material for routine and histochemical staining. In addition to haematoxylin and eosin, Masson trichrome, Congo red, thioflavine $\mathrm{T}$, periodic acid-Schiff, and Alcian blue staining methods, sections were stained for protein substances and bound lipid. In one instance (Case 2) cryostat sections were cut and examined for soluble fats. The histochemical methods employed were those described and recommended by Pearse (1968).

\section{Results}

CASE I. A MAN AGED 52 YEARS

\section{Clinical features}

Corneal opacities in the left eye were due to lattice-like lesions in the substantia propria and irregularity of the central epithelium. He had previously been subjected to penetrating keratoplasty for a similar stromal disorder in the right eye and histology had confirmed the diagnosis of lattice dystrophy. Symptoms had first been noticed at the age of 9 years.

\section{Histopathology}

Scattered within the corneal stroma were the characteristic amyloid-staining fusiform nodules of lattice dystrophy. Between the epithelium and Bowman's membrane there was a substantial layer of mature fibrous tissue, while embedded in both this and the superficial lamellae of the substantia propria were numerous globular deposits of an amorphous and predominantly acidophilic material (Figs 2 and 3). The deposits varied considerably in diameter from I $\mu$ to over oo $\mu$, the smaller being generally round or ovoid, the larger having rather less regular outlines. Bowman's membrane, though sandwiched between this abnormal material, was itself relatively uninvolved. The epithelium was variable in thickness, tending to be thinnest where it covered the larger deposits, and included scattered foci of what appeared to be individual cell keratinization, the affected cells showing increased eosinophilia and either absent or pyknotic nuclei. No abnormality was observed in either Descemet's membrane or the endothelium.

CASE 2. A 6O-YEAR-OLD MAN

\section{Clinical features}

Visual impairment attributable to long-standing bilateral corneal opacities had become markedly worse during the last 2 years. Slit-lamp examination of the left eye, in which keratoplasty was subsequently performed, showed extensive superficial scarring associated with lattice changes and what was thought to be lipoid degeneration in the stroma. His mother had been similarly affected. 


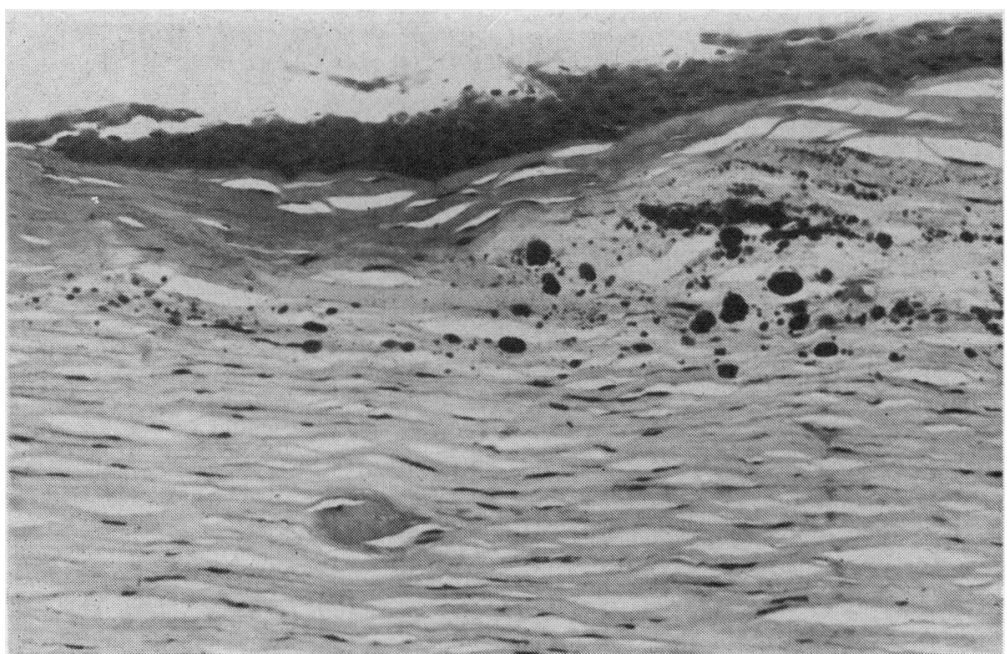

FIG. 2 Case I. There is flaking of the corneal epithelium, subepithelial fibrosis, and partial loss of Bowman's membrane. Within the superficial collagenous tissue are multiple globular deposits of a predominantly basophilic material, while at a deeper level an amyloidotic nodule characteristic of lattice dystrophy is seen. Haematoxylin and eosin. $\times 185$

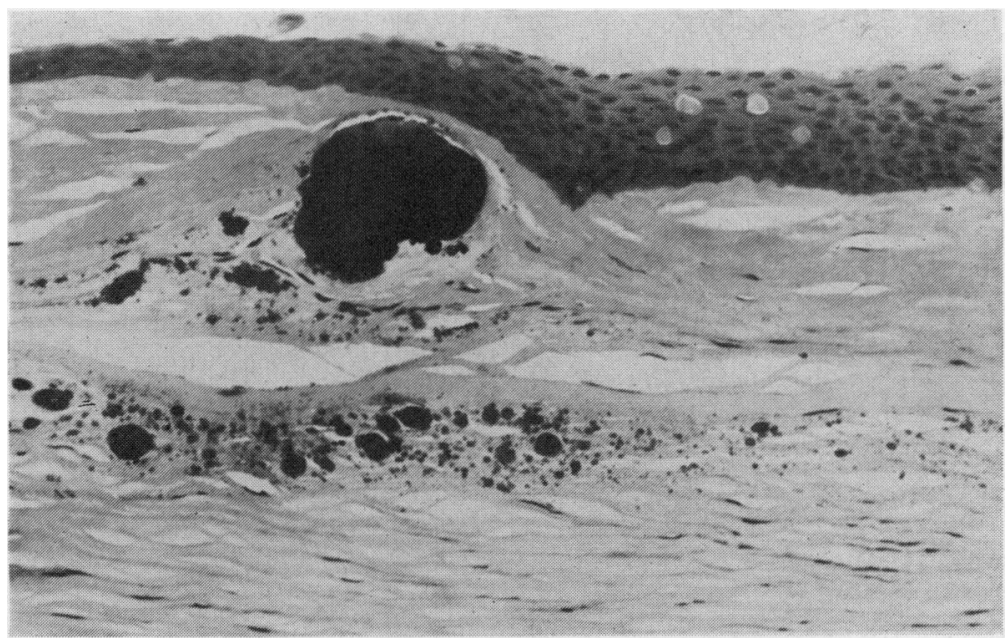

FIG. 3 Case I. The epithelium is uneven and contains foci of individual cell keratinization. Globular deposits of varying size are present in a layer of subepithelial fibrous tissue and the superficial stromal lamellae, but Bowman's membrane is relatively unaffected. Haematoxylin and eosin. $\times 185$

\section{Histopathology}

The epithelium in most parts was excessively attenuated and in places this was associated with epitheliolysis of the deeper layers. There was a band of dense eosinophilic fibrous tissue immediately beneath the epithelium, while Bowman's membrane showed occasional breaks in relation to which the underlying superficial stroma contained multiple globular deposits (Fig. 4, overleaf). The larger deposits had crenated outlines and were predominantly basophilic, whereas the smaller granular deposits were eosinophilic. The stroma also contained fusiform nodules, which stained positively for amyloid using Congo red and thioflavine $\mathrm{T}$ stains, and satisfied the criteria for a diagnosis of lattice dystrophy. Descemet's membrane and its endothelial lining were apparently normal. 


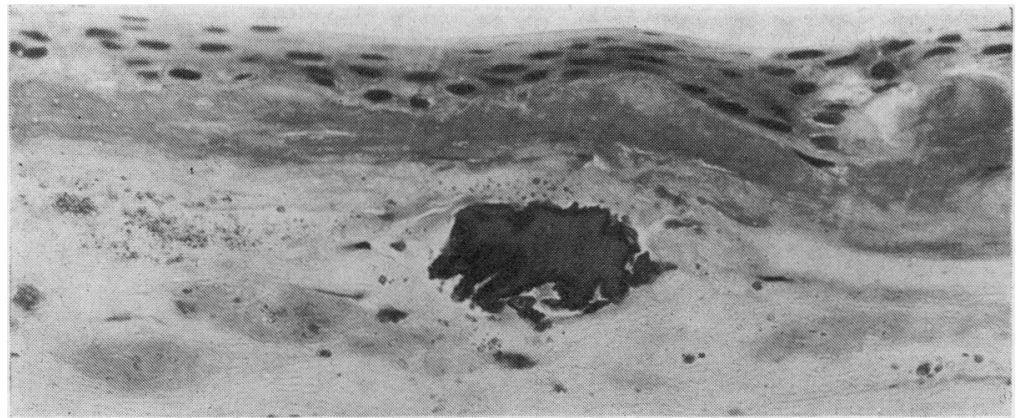

FIG. 4 Case 2. Beneath the epithelium is a band of hyalinized fibrous tissue while fusiform nodules of amyloidstaining material are present in the substantia propria. Bowman's membrane is partially destroved and the superficial stroma contains both large basophilic deposits with crenated margins and smaller eosinophilic granules. Haematoxylin and eosin. $\times 295$

\section{CASE 3. A 7O-YEAR-OLD MAN}

\section{Clinical features}

Corneal opacities had been developing for more than 50 years. Examination revealed "crystals" in the superficial cornea, epithelial facets, and a little vascularization at the periphery. Folds in Descemet's membrane were also observed.

\section{Histopathology}

Within the epithelium there were numerous instances of individual cell keratinization and some intraepithelial cysts containing similar eosinophilic material (Fig. 5).

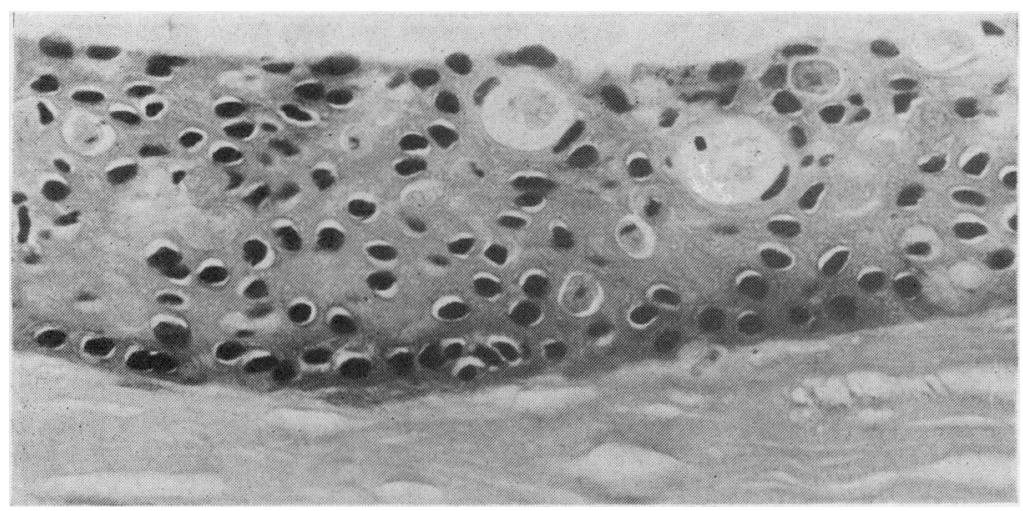

FIG. 5 Case 3. The epithelium contains many cells with pyknotic or absent nuclei and increased eosinophilia of their cytoplasm, areas of cell disintegration, and some cysts filled with degenerate cell products. Haematoxylin and eosin. $\times 375$

In places, where there were deficiencies in Bowman's membrane, epithelial facets had developed, some of which showed loss of cellular outlines and formation of confluent irregular masses of amorphous material (Figs 6 and 7). The stromal lamellae immediately beneath Bowman's membrane were impregnated with minute spherical eosinophilic granules, though the membrane itself was not affected (Fig. 8). Typical amyloid-staining nodules indicative of lattice dystrophy were present in the deeper layers of the substantia propria. 


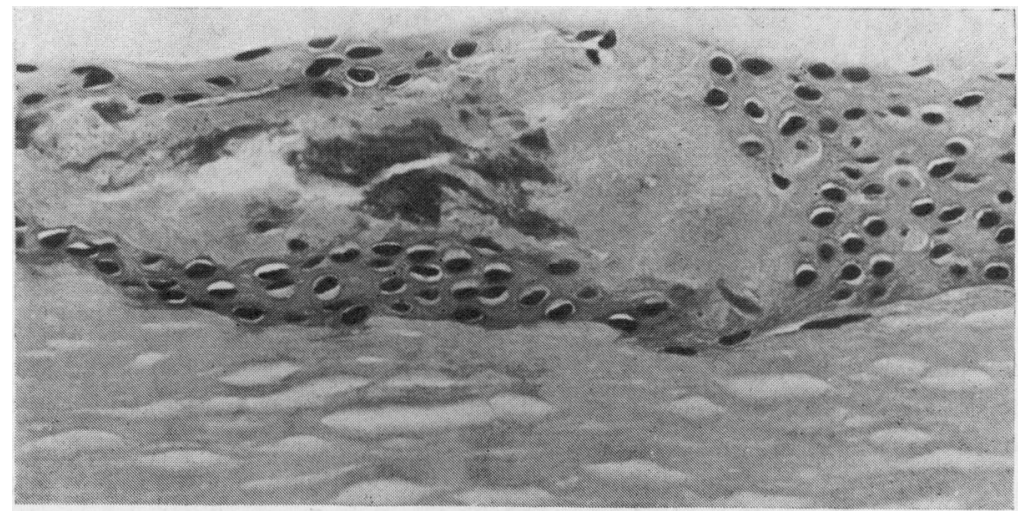

FIG. 6 Case 3. In addition to keratinization of individual cells, there are confluent areas of epithelial disintegration which, though predominantly eosinophilic, contain some basophilic material. Haematoxylin and eosin. $\times 300$

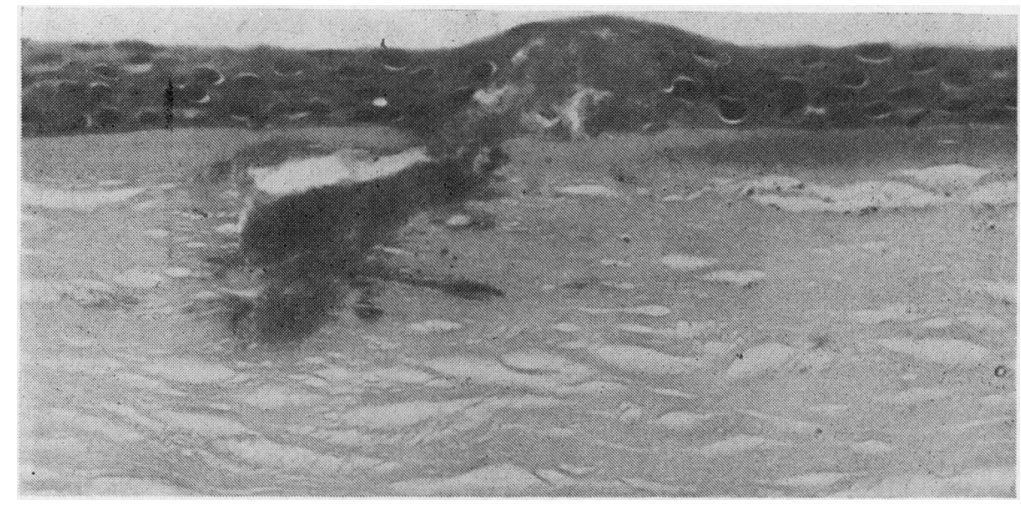

FIG. 7 Case 3. A focus of epithelial degeneration is linked via a break in Bowman's membrane to similar material in the superficial stroma. Minute granular deposits are also present immodiately beneath Bowman's membrane. Haematoxylin and eosin. $\times 300$

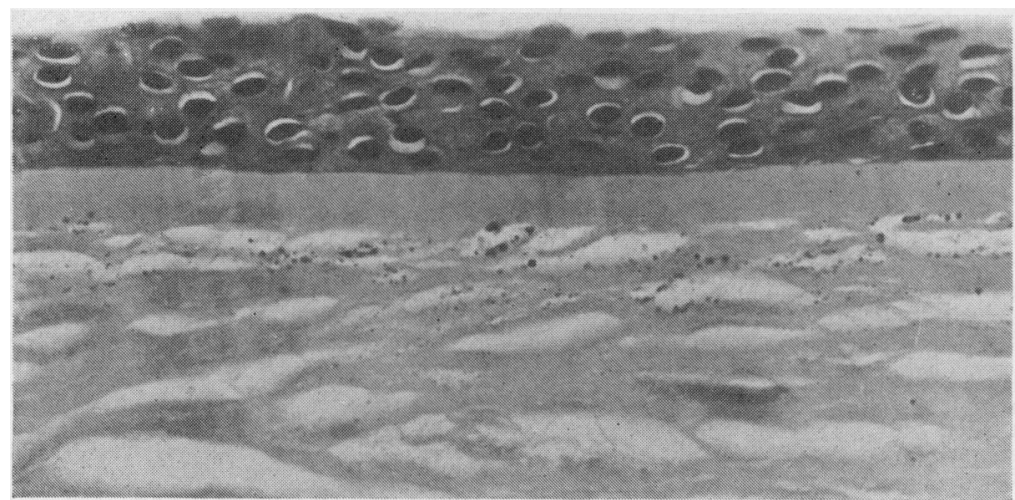

FIG. 8 Case 3. Many dyskeratotic cells are present in the epithelium while the stroma is impregnated with multiple tiny eosinophilic granules. Haematoxylin and eosin. $\times 375$ 
CASE 4. A MAN AGED 35 YEARS

\section{Clinical features}

From birth the patient had suffered from bilateral nystagmus and in recent years he had developed band-shaped corneal opacities in the region of the palpebral fissures. The disorder was apparently confined to the superficial cornea and an epithelial type of dystrophy was suspected.

\section{Histopathology}

Throughout the specimen there was subepithelial fibrosis, although in the central cornea this had been largely replaced by amyloid material (Fig. 9). The epithelium overlying the amyloid deposits was atrophic but elsewhere it was generally of normal thickness and showed flaking and desquamation of the surface cell layers (Fig. 10). The superficial stromal lamellae, particularly in the vicinity of the subepithelial amyloid, were heavily impregnated with globular deposits of homogeneous eosinophilic material, while a few solitary quite large deposits of similar material were present within the

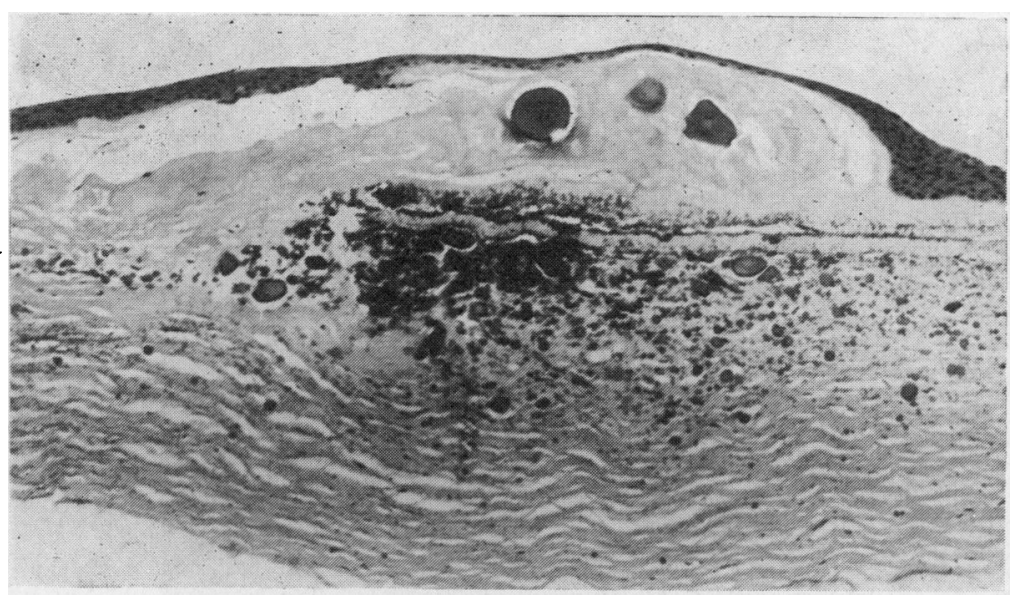

FIG. 9 Case 4. A large plaque of amyloid material is covered by attenuated epithelium and contains a few large globules of hyaline material. Similar deposits of generally smaller size are present in the superficial stroma. Haematoxylin and eosin. $\times 75$

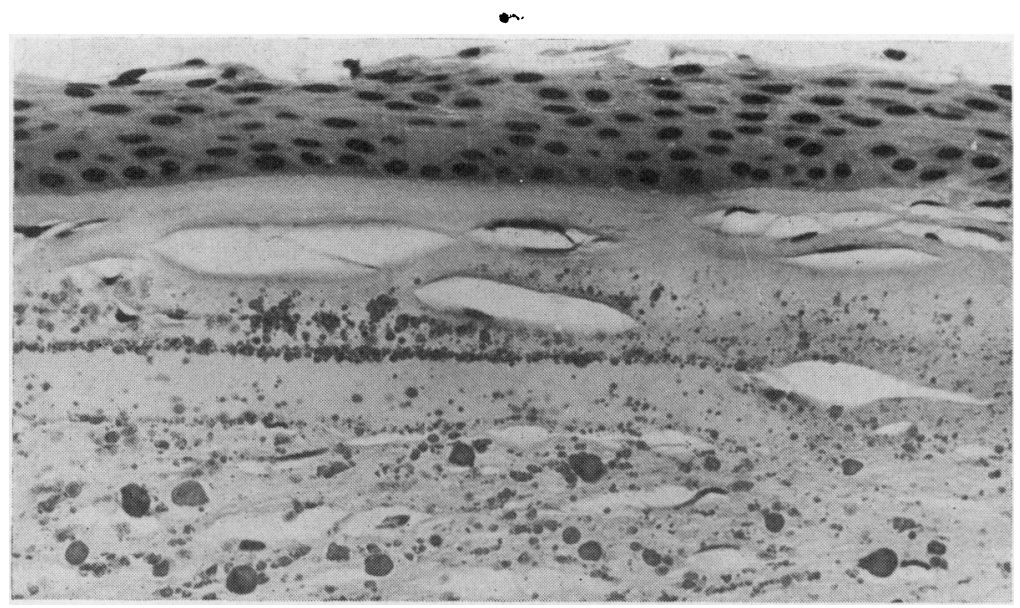

FIG. 10 Case 4. Numerous globules and granules of homogeneous eosinophilic material are present in both the superficial stroma and a zone of subepithelial fibrous tissue, but the intervening Bowman's membrane is relatively spared. There is also some flaking of the corneal epithelium. Haematoxylin and eosin. $\quad \times 295$ 
amyloid itself. Bowman's membrane was destroyed in places but was relatively less heavily infiltrated by the abnormal material than the adjacent stroma. The deep layers of the cornea seemed healthy.

CASE 5. A 52-YEAR-OLD MAN

Clinical features

After a perforating corneal injury at the age of io years a yellowish patch developed at the trauma site and this lesion had increased in size over the last 3 years. The contralateral eye was normal.

\section{Histopathology}

In the superficial stroma and many parts of the corneal epithelium there were multiple irregular masses of amorphous eosinophilic material. Those within the epithelium had crenated margins, and were not only associated with necrosis and disintegration of the adjacent cells, but also appeared to be derived from such cells in as much as some of the deposits had degenerate nuclei within them (Fig. I I). The epithelium in general was also moderately hypertrophic. Bowman's membrane was almost completely destroyed and there was some subepithelial scarring. No significant abnormality was seen in the remaining deeper parts of the cornea.

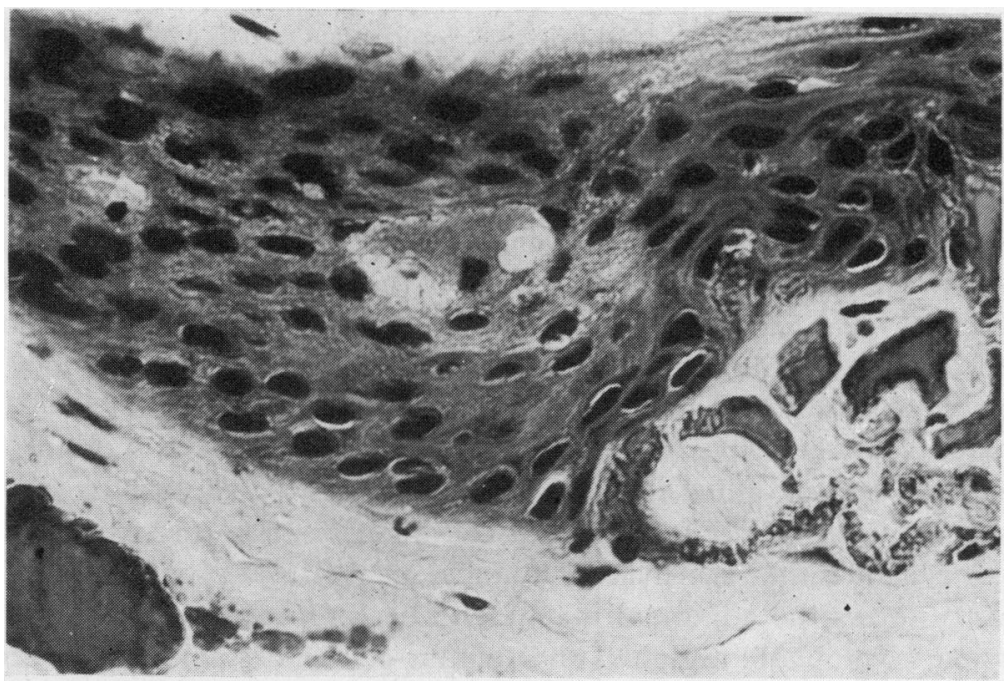

FIG. I I Case 5. The corneal epithelium includes masses with crenated margins of eosinophilic material and foci of cell degeneration. Globules of similar material are also present in the superficial stroma. Haematoxylin and eosin. $\times 480$

\section{Histochemistry}

The hyaline globular deposits, though in some instances staining weakly with haematoxylin, were predominantly eosinophilic and stained red or purple in Masson trichrome preparations. Apart from a little fine silver precipitation in Cases 4 and 5, they were essentially non-argyrophilic, although there was quite a heavy reticulin network round the deposits. They did not stain for amyloid, glycogen, or any of the mucopolysaccharides. Pyroninophilia, suggestive of ribonucleic acid, was a feature in each case, but the Feulgen reaction for desoxyribonucleic acid was uniformly negative.

Staining for protein by the coupled tetrazonium method gave a strong reaction in all five cases. Pretreatment for as long as 48 hours with benzoyl chloride had little inhibitory effect on this reaction save in Case 4 where there was complete blocking. Similarly treated control sections of keratinized skin showed retention of the coupled tetrazonium reactivity in the stratum granulosum but not elsewhere. The deposits were shown by the diazotization-coupling method (Glenner and Lillie, 1959) to be rich in tyrosine, by the 
Sakaguchi reaction (Baker, 1947) to contain abundant arginine (Fig. 12), and by the p-dimethylaminobenzaldehyde (DMAB)-nitrite method (Adams, I957) to include appreciable amounts of tryptophan. Strong reactions were also obtained by the dihydroxydinaphthyldisulphide (DDD) reaction (Barrnett and Seligman, 1952) for sulphur-containing amino-acids, the latter being predominantly of the cysteine type since, despite a somewhat more pronounced staining reaction following thioglycollate reduction of the disulphide bonds to sulphydryl groups (Fig. 13), the performic acidAlcian blue procedure for disulphide groups was negative.

In the one instance (Case 2) where frozen sections were available, staining with Oil red $O$ for neutral fats was negative as also were the reactions for phospholipid with Sudan black B and copper phthalocyanin. Sudan black staining was similarly negative in all the paraffin-embedded material though moderate amounts of phospholipid were demonstrable by this method in the overlying corneal epithelium. The osmium tetroxide$\alpha$-naphthylamine (OTAN) reaction of Adams (1959) on the other hand produced an intense reddish-brown colour suggestive of phospholipid (Fig. 14), but in so much as keratin in control skin sections gave a similar response, this interpretation is in some doubt. This doubt is reinforced by the positive performic acid-Schiff reaction observed in each of the cases (Fig. I5), a reaction which is said by Pearse (1951) to be characteristic not only of unsaturated lipids, mainly phospholipid, but also of keratin.

The histochemical reactions in individual cases are given in the Table (overleaf).

\section{Discussion}

Despite some minor variations there were sufficient morphological and histochemical similarities between the hyaline deposits in each of the five cases described to establish their common nature. The variability of the underlying pathology suggests, however, that the deposits do not constitute a specific disease entity but rather that they represent a special type of response which may have several causes.

The proximity of the deposits to, and their inclusion in some instances within, the epithelium of the cornea, allied with other signs of epithelial disturbance in the form of excessive desquamative activity, individual cell keratinization and epitheliolysis, can be construed as evidence that the hyaline material might be a product of the epithelium. Histochemistry shows the abnormal material to be composed essentially of a protein in which tyrosine, tryptophan, arginine, and sulphur-containing amino-acids are prominent constituents. Taken together with the location of the deposits and the morphological evidence of a disordered epithelium, such a composition, while by no means specific, is suggestive of a keratin-related protein: a suggestion which, in the apparent absence of phospholipid, is reinforced by the positive performic acid-Schiff reaction wherein the cystine of keratin is thought to be oxidized to form compounds capable of reacting with Schiff's reagent (Pearse, I95I).

According to Pearse (1968), keratin can be distinguished from other acidophil globular proteins of high arginine content by the negative coupled tetrazonium reaction it gives following prolonged benzoylation. Though in only one case was there complete inhibition of this reaction after such pretreatment, the positive reaction of the remainder was paralleled by persistent tetrazonium reactivity of the stratum granulosum in control skin sections. In the latter case the reactivity was almost certainly due to the presence of histidine residues derived from cellular nucleoprotein breakdown, and it is conceivable that the same explanation appertains to the corneal deposits. The pyroninophilia exhibited by these deposits also suggests that ribonucleoprotein might be a component. 


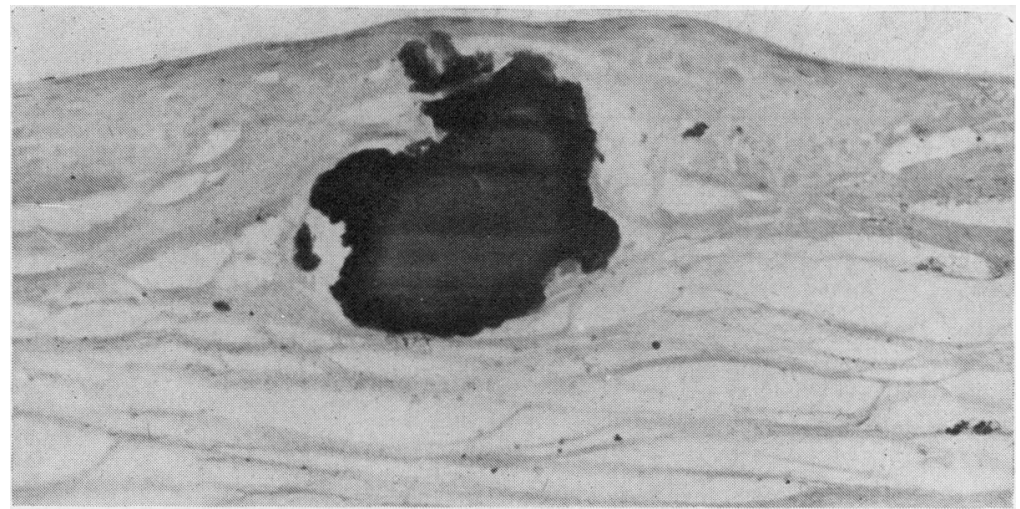

FIG. 12 Case 2.

The globular deposits react strongly for arginine. Sakaguchi reaction. $\times 185$

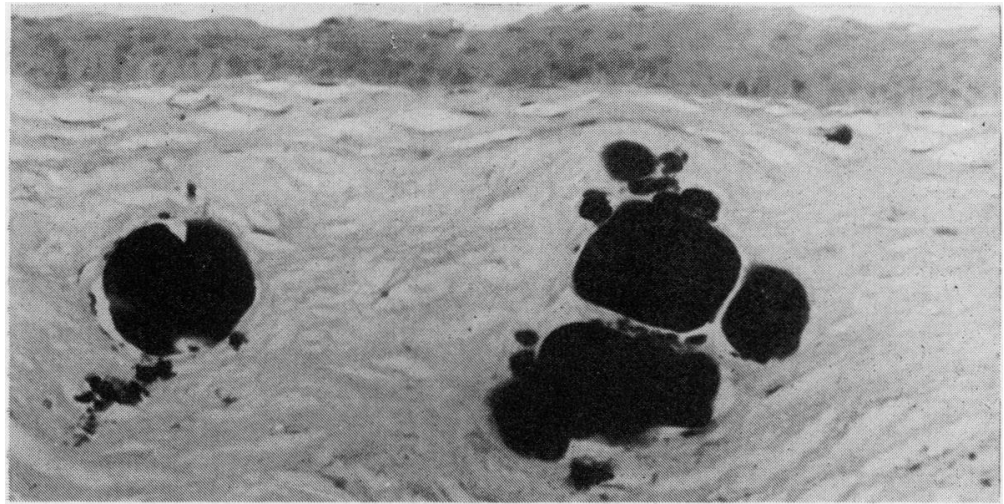

FIG. 13 Case 4. There is a marked response for sulphurcontaining amino-acids in the hyaline deposits. Thioglycollate-DDD. $\times 185$

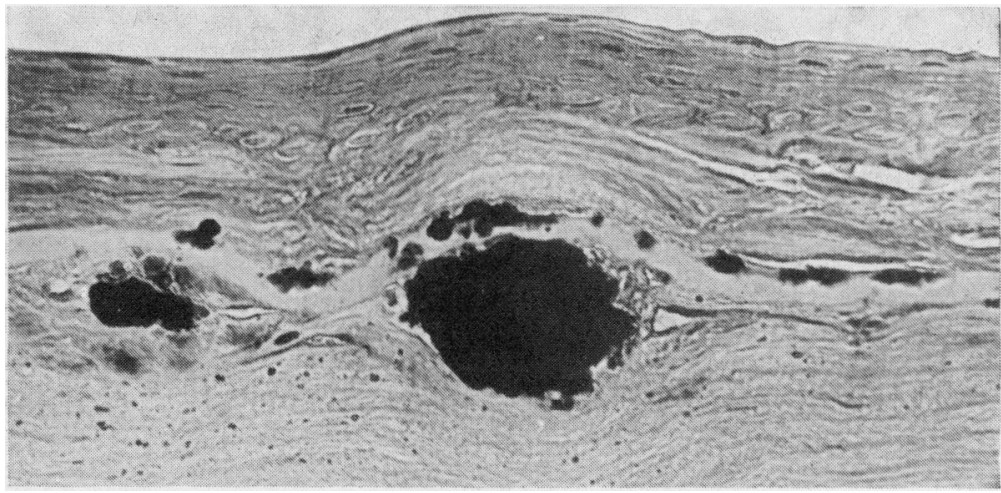

FIG. 14 Case 2.

The globular material is stained a deep reddishbrown colour. Osmium tetroxide- $\alpha$-naphthylamine reaction. $\times 300$

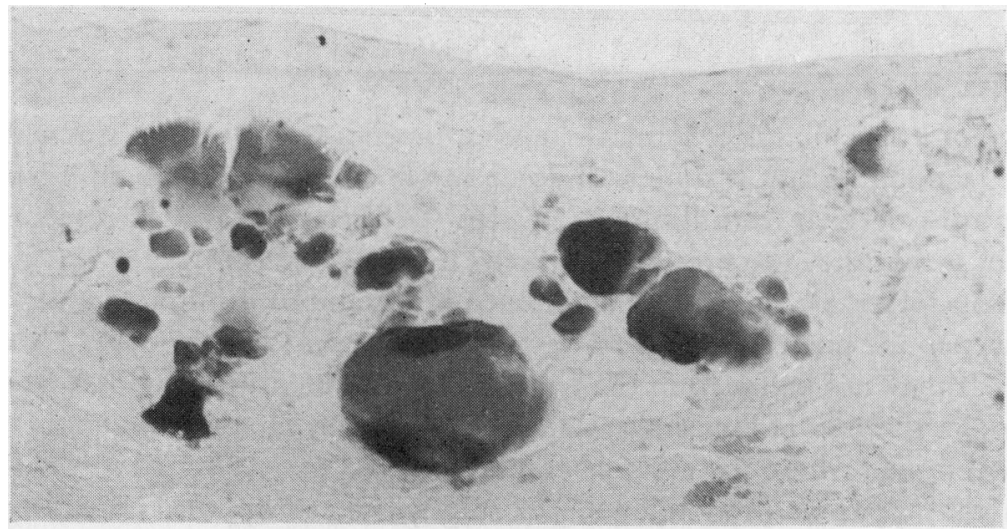

FIG. 15 Case 4. The deposits are stained rose-pink whereas the stroma is virtually colourless. Performic acid-Schiff. $\quad \times 205$ 
Table Staining reactions of globular corneal deposits

\begin{tabular}{|c|c|c|c|c|c|c|}
\hline Method & Case I & Case 2 & Case 3 & Case 4 & Case 5 & Comment \\
\hline Haematoxylin and eosin & B & B & $\mathbf{E}$ & $\mathbf{E}$ & $\mathrm{B} / \mathrm{E}$ & $\begin{array}{l}\text { Indicates predominant reaction, } \\
\text { whether basophilic (B) or eosino- } \\
\text { philic (E) }\end{array}$ \\
\hline Masson trichrome & Purple & Purple & Red/Purple & Red/Purple & Purple & \\
\hline Wilder silver method & - & - & - & \pm & \pm & $\begin{array}{l}\text { Little fine particulate deposition } \\
\text { in Cases } 4 \text { and } 5\end{array}$ \\
\hline Periodic acid-Schiff & - & - & - & - & - & Test for neutral polysaccharides \\
\hline Alcian blue, pH 2.5 & - & - & - & - & - & Test for acid polysaccharides \\
\hline Congo red & - & - & - & - & - & \}$_{T}$ enter \\
\hline Thioflavine $\mathbf{T}$ & - & - & - & - & - & $\int$ tesis ior anyiorid \\
\hline Von Kossa & 一 & - & - & - & 一 & $\begin{array}{l}\text { Eliminates calcification as a cause } \\
\text { of the basophilia in Cases } I \text { and } 2\end{array}$ \\
\hline Feulgen & - & - & - & - & - & $\begin{array}{l}\text { Excludes presence of desoxyribo- } \\
\text { nucleic acid (DNA) }\end{array}$ \\
\hline Methyl green-Pyronin & Pink & Green/Pink & Pink & Pink & Pink & $\begin{array}{l}\text { Pink colour given by ribonucleic } \\
\text { acid, green by DNA }\end{array}$ \\
\hline Coupled tetrazonium & ++ & +++ & +++ & +++ & ++ & General reaction for protein \\
\hline $\begin{array}{l}\text { Coupled tetrazonium } \\
\text { after benzoylation }\end{array}$ & ++ & ++ & ++ & - & ++ & $\begin{array}{l}\text { Positive reaction after } 48 \text { hours } \\
\text { benzoylation is suggestive of } \\
\text { histidine-containing nucleo- } \\
\text { protein residues: negative } \\
\text { reaction is typical of keratin }\end{array}$ \\
\hline Diazotisation-coupling & + & ++ & ++ & ++ & ++ & Indicates presence of tyrosine \\
\hline $\begin{array}{l}\text { p-Dimethylamino- } \\
\text { benzaldehyde } \\
\text { (DMAB)-nitrite }\end{array}$ & + & + & + & + & ++ & Indicates presence of tryptophan \\
\hline Sakaguchi reaction & ++ & ++ & + & ++ & ++ & Indicates presence of arginine \\
\hline $\begin{array}{l}\text { Dihydroxy-dinaphthyl } \\
\text { disulphide (DDD) }\end{array}$ & + & ++ & ++ & ++ & ++ & $\begin{array}{l}\text { Indicates presence of sulphydryl } \\
\text { groups }\end{array}$ \\
\hline Thioglycollate-DDD & ++ & +++ & ++ & ++ & ++ & $\begin{array}{l}\text { Indicates presence of combined } \\
\text { sulphydryl and disulphide groups }\end{array}$ \\
\hline $\begin{array}{l}\text { Performic acid-Alcian } \\
\text { blue }\end{array}$ & - & - & - & - & - & Test for disulphide groups \\
\hline Performic acid-Schiff & \pm & + & + & + & + & $\begin{array}{l}\text { Indicates presence of unsaturated } \\
\text { lipid or keratin }\end{array}$ \\
\hline Oil red $O$ & & - & & & & $\begin{array}{l}\text { Test for neutral fat applicable } \\
\text { to frozen sections }\end{array}$ \\
\hline Sudan black B & - & - & - & - & - & Test for phospholipid \\
\hline Copper phthalocyanin & & - & & & & $\begin{array}{l}\text { Stain for gangliosides and most } \\
\text { phospholipids }\end{array}$ \\
\hline $\begin{array}{l}\text { Osmium tetroxide- } \alpha- \\
\text { naphthylamine } \\
\text { (OTAN) }\end{array}$ & Red-brown & Red-brown & Red-brown & Red-brown & Red-brown & $\begin{array}{l}\text { Phospholipid gives orange-red } \\
\text { colour, but keratin in control } \\
\text { skin sections also gave red-brown } \\
\text { colour }\end{array}$ \\
\hline
\end{tabular}

The lack of a specific histochemical staining procedure for keratin is regrettable from a diagnostic standpoint, but is understandable in view of the variable amino-acid composition of keratins derived from different sources (Mercer, 196 ra). A current definition of the keratins is that they are proteins produced by epithelial cells which are insoluble in the usual protein solvents because of the presence of numerous disulphide bonds between the constituent peptide chains (Mercer, Munger, Rogers, and Roth, I964). Mercer (196Ib) adds that "it may not be far from the truth to say that keratinization is a fate which could befall any of a number of kinds of protein, provided they contain enough cysteine . . . in a biochemical milieu where the cysteine can be oxidized to cystine". In the light of such a definition the apparent predominance of sulphydryl, as opposed to disulphide, groups 
implies that if the protein in question is indeed related to keratin it is likely to be a precursor or immature form. Moreover, according to Mercer (I96Ic), keratin is thought to consist of a fibrous moiety ( $\alpha$-component) embedded in an amorphous sulphur-rich matrix ( $\gamma$-component) in which case the corneal deposits under review correspond most closely to the $\gamma$-component.

Clinically the deposits may resemble oil droplets and in the study of a single case Volpi and Serra ( 1967 ) demonstrated fat by the Sudan III method in flat preparations of unfixed material. Frozen sections in Case 3 of the present series, however, did not reveal any evidence of neutral fat, while the persistence of the globules in paraffin-embedded material indicates that lipid is not a prominent constituent. Nevertheless, phospholipid, particularly when it is combined with protein as in the lipoproteins, frequently withstands the paraffin-embedding procedure and it is important therefore to note that staining with Sudan black was uniformly negative, despite the demonstration of phospholipid by this method in the surrounding stroma and intact epithelium. Nor, because of their crossreactivity with keratin in control skin sections, can the positive reactions in the OTAN and performic acid-Schiff procedures be taken to indicate the presence of phospholipid.

In the past it has variously been suggested that the globular deposits are the result of stromal or scar tissue degeneration, infiltration of the epithelium being a secondary phenomenon (Beselin, I886; Kamocki, I892; Sachsalber, I90 ; Parsons, I904), the outcome of extravasated blood cell degeneration (von Hippel, I895), or coagulated serous exudate (Birch-Hirschfeld, I889). There is little evidence to support any of these views, since the histochemical findings are not consistent with the abnormal material being a connective tissue derivative and there was no sign of vascularization in any of the corneae examined. The present findings accord most closely with the view of Baquis (1898) that the deposits might in part be an epithelial secretion.

There is no clear indication as to the cause of the abnormal protein formation, though it may prove to be relevant that there was either subepithelial fibrosis or superficial stromal scarring in all five cases examined.

To coin an acceptable terminology for the globular deposits is difficult but important, since the terms previously employed, such as "hyaline degeneration" (Duke-Elder and Leigh, 1965) or even "a special type of hyaline degeneration" (Parsons, 1904) or "degeneratio hyaloidea granuliformis" (Kozlowski, I953), are either inadequate or cumbersome or both. Despite some reason afforded by the appearance and possible derivation of the deposits, it would be inappropriate to employ the name "keratohyaline" since this term is properly reserved for the basophilic granules present in the stratum granulosum of epidermis which contain no demonstrable sulphydryl or disulphide groups (Montagna, 1956). In view of the resemblance of the abnormal protein to prekeratin it is, however, perhaps justifiable to propose that the process be called keratinoid corneal degeneration or keratopathy, using the term to imply a special type of corneal reaction rather than to describe an aetiological disease entity. The word keratinoid is advocated to denote resemblance to prekeratin without necessarily implying that the material is keratin itself.

\section{Summary}

Globular hyaline deposits in the superficial stroma and epithelium of the cornea have been recognized under a variety of names for many years. Sometımes seen as an isolated phenomenon, they are usually observed in association with other corneal disorders, and the present report is concerned with their occurrence in three cases of lattice dystrophy, one of subepithelial corneal fibrosis, and one of post-traumatic scarring. 
The location of the deposits in the superficial corneal tissue and on occasion within the epithelium, linked with frequent signs of epithelial disturbance in the form of excessive desquamation, individual cell keratinization, and epitheliolysis, is circumstantial evidence for their having an epithelial origin. Histochemical analysis indicates that the deposits are composed essentially of protein and suggests that they may be related to keratin, possibly as a precursor or incomplete form.

In the absence of an existing satisfactory terminology, it is proposed that the process wherein the sulphur-rich globular deposits are formed be referred to as keratinoid corneal degeneration.

The multiplicity of the corneal disorders in which the abnormal material is formed implies that the keratinoid deposits do not constitute a separate disease entity so much as a special type of response which may be stimulated in a variety of ways.

The author is greatly indebted to Prof. Norman Ashton for his advice and encouragement, to Mr. A. McNeil for technical assistance, and to Miss K. Stedman for secretarial help.

\section{References}

adams, c. W. M. (1957) J. clin. Path., ro, 56

(1959) 7. Path. Bact., 77, 648

BAKER, J. R. (1947) Quart. F. micr. Sci., 88, 463

BAQUis, E. (1898) v. Graefes Arch. Ophthal., 46, 553

BARRnetT, R. J., and SEligman, A. M. (1952) J. nat. Cancer Inst., 13, 215

BESELIN, O. (1886) Arch. Augenheilk., 16, 130

Best, (1900) Beitr. Augenheilk., 5, 229 (No. 43)

BIETt, G. B. (1962) "XIX Concilium Ophthalmologicum, 1962, India, Acta", vol. 1, p. 421.

Pandit, Bombay

BIRCH-HIRSGHFELD, A. (1899) v. Graefes Arch. Ophthal., 48, 328

DUKE-ELDER, s., and LeIGH, A. G. (1965) "System of Ophthalmology", vol. 8, pt. 2, p. 888.

Kimpton, London

GLENNER, G. G., and LILlE, R. D. (1959) J. Histochem. Cytochem., 7, 416

HIPPEL, E. von (1895) $\quad$ v. Graefes Arch. Ophthal., 4r, pt. 3, p. 13

KAMOCKI, v. (1892) Arch. Augenheilk., 25, 209

Kozıowski, B. (1953) Klin. oczna, 23, 249

LUGL, L. (1935) v. Graefes Arch. Ophthal., 134, 2 I 1

MERCER, E. H. (1961a) "Keratin and Keratinization. An Essay in Molecular Biology", p. 9.

Pergamon, Oxford

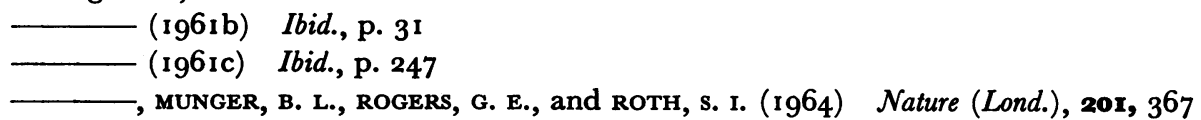

MONTAGNA, w. (I956) "The Structure and Function of Skin", p. 42. Academic Press, New York PARSONS, J. H. (1904) "The Pathology of the Eye", vol. I, pp. 97, 241. Hodder and Stoughton,

London

PEARSE, A. G. E. (195I) Quart. F. micr. Sci., 92, 393

(1968) "Histochemistry, Theoretical and Applied", 3rd ed., vol. I, pp. 6o6, 687.

Churchill, London

Recklinghausen, F. O. von (1883) "Handbuch der allgemeines Pathologie des. Kreislaufs und der

Ernährung", in "Deutsche Chirurgie", Lieferung 2/3. Enke, Stuttgart

SACHSAlber, A. (1901) Beitr. Augenheilk., 5, 865 (no. 48, p. I)

VOLPI, U., and SERRA, A. (1967) Ann. Ottal., 93, I305

WEDL, c. (186I) “Atlas der pathologischen Histologie des Auges", teil IV, fig. 37. Georg Wigand's

Verlag, Leipzig 